\section{Mitochondrial DNA defects in diabetes mellitus}

Dear Sir,

The hypothesis that mitochondrial DNA might play a role in the pathogenesis of diabetes is not new. However, the recent outline of the possible mechanisms involved is useful [1].

In 1991 we demonstrated a strong maternal effect in the transmission of Type 2 (non-insulin-dependent) diabetes mellitus [2]. Thus, of patients with Type 2 diabetes and an affected parent, $75 \%$ had affected mothers as opposed to the $50 \%$ which would be predicted by Mendelian genetics. This finding has been confirmed by other groups $[3,4]$. Some workers have suggested this maternal transmission may be related to the role of the intra-uterine environment in the development of the disease [5].

The possibility that mitochondrial gene defects inherited along the maternal line could explain the observed maternal transmission was discussed in our original paper and in greater length in a recent thesis [6]. These findings, together with those cited by Gerbitz [1], have prompted us to search for mitochondrial mutations in Type 2 diabetes. To date we are aware of three families with Type 2 diabetes in which the disease segregates with a specific mitochondrial DNA mutation. One of these families has recently been reported on by another group [7] and is probably the same pedigree previously reported as carrying a BstN1 polymorphism [8] and cited by Gerbitz [1].

I would take issue with the use of the term 'evolution' by Gerbitz [1] to describe de novo mutations in the mitochondrial DNA, since there is no evidence that such random mutations lead to any beneficial effect in mammalian cells.

Any discussion on the role of mitochondrial mutations in diabetes also needs to take into account the phenomenon of heteroplasmy whereby individuals possessing a mitochondrial mutation will have differing numbers of normal and mutated mitochondria in different cells of the body [9]. In diabetes, the beta cell, liver or muscle may play an important part in primary disease pathogenesis. The finding of mitochondrial DNA mutations by employing polymerase chain reaction (PCR) techniques in peripheral blood may not accurately reflect the number of mutated mitochondria in the tissue of most interest to the diabetologist.

Finally, I think it important to mention that not all mitochondrial diseases will show maternal transmission since mitochondrial gene expression is controlled by nuclear-DNA-coded proteins [10]. A defect of nuclear DNA can therefore produce defective mitochondrial function. Thus, the reported excess of paternal transmission in Type 1 diabetes does not rule out the possibility of a mitochondrial defect in the disease.

Despite the concluding paragraph of Gerbitz [1], I would suggest that current evidence points to mitochondrial defects being potentially more important in Type 2 than Type 1 (insulin-dependent) diabetes.

Yours sincerely,

J.C. Alcolado

\section{References}

1. Gerbitz KD (1992) Does the mitochondrial DNA play a role in the pathogenesis of diabetes? Diabetologia 35:1181-1186

2. Alcolado JC, Alcolado R (1991) Importance of maternal history of non-insulin dependent diabetic patients. BMJ 302: 1178-1180

3. Korugan U, Yilmaz F, Sipahioglu H et al. (1991) The Istanbul family study. Diabetologia 34 (Suppl 2): A117

4. Dorner G, Mohnike A (1976) Further evidence for a predominantly maternal transmission of maturity-onset type diabetes. Endokrinologie 68: 121-124
5. Hales CN, Barker DJ (1992) Type 2 (non-insulin-dependent) diabetes mellitus: the thrifty phenotype hypothesis. Diabetologia 35: 595-601

6. Alcolado JC (1992) The genetics of non-insulin dependent diabetes mellitus. DM Thesis 1992; Southampton University, England.

7. van den Ouweland JMW, Lemkes HHPJ, Ruitenbeek W et al. (1992) Mutation in mitochondrial tRNA gene in a large pedigree with maternally transmitted type II diabetes mellitus and deafness. Nature Genetics 1: 368-371

8. van den Ouweland JMW, Lemkes H, Maassen JA (1991) A rare mitochondrial BstN1 polymorphism in a family with type 2 diabetes. Nucleic Acids Res 19: 1962

9. Lertrit P, Noer AS, Byrne E, Marzuki S (1992) Tissue segregation of a heteroplasmic mtDNA mutation in MERRF (myoclonic epilepsy with ragged red fibres) encephalomyopathy. Hum Genet 90:251-254

10. Zeviani M (1992) Nucleus-driven mutations of human mitochondrial DNA. J Inherited Metab Dis 15: 455-471.

Dr. J.C. Alcolado

Department of Medicine

Prince Charles Hospital

Gurnos Road

Merthyr Tydfil

Wales

UK

\section{Response from the author}

Dear Sir,

The predominantly maternal transmission of Type 2 (non-insulindependent) diabetes has been known for a long time [1]; evidence that mutations of the mIDNA could account for this phenomenon is new. Several publications also on this topic have recently appeared [2-4] which confirm my hypothetical question. Hopefully, the Type 2 diabetic families with specific mtDNA mutations mentioned by Dr. Alcolado will be published in the near future. Deletions, duplications and defined mtDNA point mutations are not only found in families with maternally inherited diabetes, but also in pedigree members suffering from both mitochondrial encephalomyopathy and diabetes [5-11] (Table 1). In none of the respective cases described so far is diabetes the only symptom; there is always an association with neurological symptoms (deafness, ataxia, etc.) usually not combined with diabetes. Thus, it seems likely that those forms of diabetes which have been described as being associated with mtDNA defects do not belong to the classic idiopathic Type 1 (insulin-dependent) or Type 2 diabetes. They may represent subclassi-

Table 1. See text

\begin{tabular}{rlllll}
\hline Ref. & $\begin{array}{l}\text { Diabetes } \\
\text { type }\end{array}$ & $\begin{array}{l}\text { Single } \\
\text { case }\end{array}$ & $\begin{array}{l}\text { Familial } \\
\text { cases }\end{array}$ & $\begin{array}{l}\text { mtDNA } \\
\text { mutation }\end{array}$ & $\begin{array}{l}\text { Hetero- } \\
\text { plasmy }\end{array}$ \\
\hline 2 & IDDM & & $\mathrm{x}$ & deletion & $\mathrm{x}$ \\
6 & IDDM & $\mathrm{x}$ & & deletion & $\mathrm{x}$ \\
7 & IDDM & $\mathrm{x}$ & & $\begin{array}{l}\text { deletion } \\
\text { del. + duplication }\end{array}$ & $\mathrm{x}$ \\
8 & IDDM & $\mathrm{x}$ & & duplication & $\mathrm{x}$ \\
9 & IDDM & mother- & $\mathrm{x}$ & & \\
& & child & & tRNA Leu-nt 3243 & $\mathrm{x}$ \\
3 & NIDDM & & $\mathrm{x}$ & tRNA Leu-nt 3243 & $\mathrm{x}$ \\
4 & IDDM/NIDDM & $\mathrm{x}$ & tRN \\
5 & IDDM/NIDDM & $\mathrm{x}$ & tRNA Leu-nt 3243 & $\mathrm{x}$ \\
10 & IDDM & & $\mathrm{x}$ & tRNA Leu-nt 3243 & $\mathrm{x}$ \\
11 & IDDM & $\mathrm{x}$ in a pedigree & tRNA Leu-nt 3260 & $\mathrm{x}$ \\
\hline
\end{tabular}


fications which are part of syndromic disorders mainly affecting tissues of neuroectoderm origin.

As mentioned by Dr. Alcolado, mitochondrial genetics are characterized by some remarkable peculiarities. MtDNA molecules within a cell can interact and can complement each other. They undergo replicative segregation; which means that the proportions of mutant and wild-type mtDNA (heteroplasmy) that are distributed to daughter cells can fluctuate resulting in a progressive drift towards either pure mutant or wild-type mtDNA (homoplasmy). Thus, even subjects with identical nuclear genotypes, such as monozygotic twins, can differ in their mitochondrial genotype, a fact which should be kept in mind with respect to the discordance of Type 1 diabetes in "identical" twins. The association between MELAS and diabetes or, in other words, between the mitochondrial tRNA $^{\text {Leu (UUR) }}$ point mutation at nt 3243 and diabetes is a model for pathogenesis [12]. This mutation is usually found in a heteroplasmic form. It seems to produce increased amounts of a novel unprocessed RNA species, which is proposed to be incorporated into mitochondrial ribosomes, rendering them functionally deficient [12]. With respect to replication the tRNA ${ }^{\text {Leu (UUR) }}$ mutation has a marked advantage against the wild-type genome as recently demonstrated in cell culture studies [13]. Threshold expression is a further feature of mtDNA genetics. This means that different organs rely on energy production to a different degree and therefore also have different thresholds with respect to the nature and the percentage of mutated mtDNA. Up to now it is unclear what factors regulated mitochondrial disease expression resulting in encephalomyopathies on one site and in endocrinopathies such as diabetes on the other site. As our understanding of the mitochondrial genetics matures, valuable insights into common disease mechanisms are likely to emerge also in the field of mutual effects between the nucleus and the mitochondrion.

Yours sincerely,

\section{K.-D. Gerbitz}

\section{References}

1. Dorner G, Mohnike A, Steindel E (1975) On possible genetic and epigenetic modes of diabetic transmission. Endokrinologie 66: 225-227

2. Ballinger SW, Shoffner JM, Hedaya EV et al. (1992) Maternally transmitted diabetes and deafness associated with a $10.4 \mathrm{~kb}$ mitochondrial DNA deletion. Nature Genetics 1:11-15

3. van den Ouweland JMW, Lemkes HHPJ, Ruitenbeek W et al. (1992) Mutation in mitochondrial tRNA ${ }^{\text {Leu (UUR) }}$ gene in a large pedigree with matemally transmitted type II diabetes and deafness. Nature Genetics 1: 368-371

4. Reardon W, Ross RJW, Sweeney MG et al. (1992) Diabetes mellitus associated with a pathogenic point mutation in mitochondrial DNA. Lancet 340: 1376-1379

5. Obermaier-Kusser B, Paetzke-Brunner I, Enter C et al. (1991) Respiratory chain activity in tissues from patients (MELAS) with a point mutation of the mitochondrial genome (tRNA ${ }^{\text {Leut }}$ (UUR) FEBS Lett 286: 67-70

6. Majander A, Suomaleinen A, Vettenranta K et al. (1991) Congenital hypoplastic anemia, diabetes and severe renal tubular dysfunction associated with a mitochondrial DNA deletion. Pediatr Res 30: 327-330

7. Zupanc ML, Moraes CT, Shanske S et al. (1991) Deletions of mitochondrial DNA in patients with combined features of KearnsSayre and MELAS syndromes. Ann Neurol 29: 680-683

8. Superti-Furga A, Schoenle E, Tuchschmid P et al. (1993) Pearsons bone marrow pancreas syndrome with insulin-dependent diabetes mellitus, progressive renal tubulopathy, organic aciduria and elevated fetal haemoglobin caused by deletion and duplication of mitochondrial DNA. Eur J Pediatr 152:44-50

9. Rötig A, Bessis JL, Romero N et al. (1992) Maternally inherited duplication of the mitochondrial genome in a syndrome of proxi- mal tubulopathy, diabetes mellitus and cerebellar ataxia. Am J Hum Genet 50: 368-371

10. Inui K, Fukushima H, Tsukamoto $\mathrm{H}$ et al. (1992) Mitochondrial encephalomyopathies with the mutation of the mitochondrial tRNA $^{\text {Len }(U U R)}$ gene. J Pediatr 120:62-66

11. Zeviani M, Gellera C, Antozzi C et al. (1991) Maternally inherited myopathy and cardiomyopathy: association with mutation in mitochondrial tRNA ${ }^{\text {Leu (UUR) }}$. Lancet 338: 143-147

12. Schon EA, Koga Y, Davidson M et al. (1992) The mitochondrial tRNA ${ }^{\text {Leu (UUR) }}$ mutation in MELAS: a model for pathogenesis. Biochim Biophys Acta 1101: 206-209

13. Yoneda M, Chomyn A, Martinuzzi A et al. (1992) Marked replicative advantage of human mtDNA carrying a point mutation that causes the MELAS encephalomyopathy. Proc Natl Acad Sci USA 89:11164-11168

Dr. K-D. Gerbitz

Institute für Klin. Chemie und Diabetesforschung

Krankenhaus München-Schwabing

Kölner Platz 1

W-8000 München 40

Germany

\section{Pulmonary function in Type 1 (insulin-dependent) diabetes mellitus}

Dear Sir,

Dr. K.Strojek and co-workers evaluated the influence of Type 1 (insulin-dependent) diabetes mellitus upon the main pulmonary function tests [1]. They demonstrated no significant disturbance of spirometric parameters, while the diffusing capacity in the diabetic patients with microvascular complications was lower than in both the diabetic patients without complications and the control group.

We assessed the pulmonary function in a group of 68 ( 38 female, 30 male) young diabetic subjects with and without persistent microalbuminuria (defined as albumin excretion rate $>20 \mu \mathrm{g} \cdot \mathrm{min}^{-1}$. $1.73 \mathrm{~m}^{2-1}$ ); their ages ranged from 6.01 to 22.0 (mean \pm SD $15.25 \pm$ 6.77) years, the height from 117 to $179(147.1 \pm 29.6) \mathrm{cm}$ and the duration of disease from 1 to $247(59.31 \pm 74.17)$ months. The diabetic subjects showed no retinopathy or peripheral and autonomic neuropathy. None of the subjects smoked. We subdivided the subjects into two groups according to the presence of persistent microalbuminuria. Persistent microalbuminuria was defined as an albumin excretion rate greater than $20 \mu \mathrm{g} / \mathrm{min}$ in at least three overnight urine collections taken during the previous year,

Moreover, we subdivided the subjects into three groups according to their glycated haemoglobin levels $\left(\mathrm{HbA}_{1 \mathrm{c}}<8.5 \%, \mathrm{HbA}_{1 \mathrm{c}} 8.5-\right.$ $\left.10.0 \%, \mathrm{HbA}_{\mathrm{Ic}}>10.0 \%\right)$.

We performed the same measurements as Strojek and co-workers and our subjects, considered as a whole and divided into the different groups, showed normal values. Our data revealed no significant deviation of lung function from normal parameters in Type 1 diabetes. Moreover, the presence of microalbuminuria, as well as the quality of metabolic control, did not seem to influence the pulmo nary function.

In childhood and adolescence pulmonary function seems to be normal in subjects with and without microalbuminuria. Probably, the young age can partially explain our results.

On the other hand, other authors [2-4] have demonstrated that among the long-term complications, the limited joint mobility (perhaps a clinical marker of abnormal collagen), is often present in subjects with abnormal lung volumes. In our series, no patient suffered from limited joint mobility.

We fully agree with the conclusion of Strojek and co-workers [1], but we suggest an alternative explanation: the disturbances of dynamic compliance could be due to a genetic factor, perhaps involving an abnormality in collagen structure, which can be linked to the genetic predisposition to Type 1 diabetes. In order to clarify this 